\title{
Canadian Oil Sands Extraction and Upgrading: A Synthesis of the Data on Energy Consumption, $\mathrm{CO}_{2}$ Emissions, and Supply Costs
}

\author{
Rui Xing ${ }^{1}$, Diego V. Chiappori ${ }^{1}$, Evan J. Arbuckle ${ }^{1}\left(\mathbb{D}\right.$, Matthew T. Binsted ${ }^{2}$ and Evan G. R. Davies ${ }^{1, *(1)}$ \\ 1 Department of Civil and Environmental Engineering, University of Alberta, 9211-116 St NW, \\ Edmonton, AB T6G 1H9, Canada; rxing1@ualberta.ca (R.X.); chiappor@ualberta.ca (D.V.C.); \\ ejarbuck@ualberta.ca (E.J.A.) \\ 2 Joint Global Change Research Institute, Pacific Northwest National Laboratory, 5825 University Research \\ Court, Suite 3500, College Park, MD 20740, USA; matthew.binsted@pnnl.gov \\ * Correspondence: evan.davies@ualberta.ca
}

\section{check for} updates

Citation: Xing, R.; Chiappori, D.V.; Arbuckle, E.J.; Binsted, M.T.; Davies, E.G.R. Canadian Oil Sands Extraction and Upgrading: A Synthesis of the Data on Energy Consumption, $\mathrm{CO}_{2}$ Emissions, and Supply Costs. Energies 2021, 14, 6374. https://doi.org/10.3390/en14196374

Academic Editors: Peter V. Schaeffer, Jesús Manuel Riquelme-Santos and João Fernando Pereira Gomes

Received: 16 July 2021

Accepted: 30 September 2021

Published: 5 October 2021

Publisher's Note: MDPI stays neutral with regard to jurisdictional claims in published maps and institutional affiliations.

Copyright: (c) 2021 by the authors. Licensee MDPI, Basel, Switzerland. This article is an open access article distributed under the terms and conditions of the Creative Commons Attribution (CC BY) license (https:/ / creativecommons.org/licenses/by/ $4.0 /)$.

\begin{abstract}
As Canadian crude bitumen production from oil sands has increased in recent decades, the nation's oil and gas industry has become a significant contributor to national greenhouse gas emissions. Canada has developed carbon emission reduction targets to meet its Nationally Determined Contributions and Mid-Century Strategy goals. A detailed profile of energy consumption pathways in the oil sands industry is necessary to identify potential areas of improvement and to monitor progress toward meeting emissions reduction targets. Much of the existing literature for oil sands modeling provides input assumptions with different technological boundaries. For a set of oil sands extraction and upgrading technologies, this study first reviews the literature and then quantifies energy input requirements, $\mathrm{CO}_{2}$ emissions, and operating costs for a set of consistent technological boundaries and energy units. Summary results refer to requirements and costs at the production facility, excluding transportation and blending costs. An energy system diagram of oil sands production that matches these boundaries is provided, which can be used by integrated assessment models, oil sands companies, and government ministries to evaluate the present and future energy consumption and emissions pathways of the oil sands industry.
\end{abstract}

Keywords: oil sands; $\mathrm{CO}_{2}$ emissions; energy input; energy supply costs; industrial energy consumption; energy system modeling; Canada

\section{Introduction}

Canada's oil sands are one of the largest unconventional fossil fuel reserves in the world, comprising 10\% of the global total [1]. Crude bitumen production in Canada has increased significantly over the past four decades, from 47.4 thousand barrels per day (bpd) in 1975 to 2530 thousand bpd in 2015. The application of one particular technology, in situ production, has increased about 400 -fold during this time period [2]. Canadian crude oil production is projected to increase by 1.27 million bpd, or $1.44 \%$ per year, to 5.86 million bpd by 2035 [3].

Over the next 10 years, the oil sands industry is expected to pay an estimated CAD 230 billion in provincial and federal taxes [4] - although the COVID-19 pandemic is likely to reduce these figures [5]. Oil sands development yields significant economic benefits, but it also has negative environmental impacts, including deforestation [6], emissions of greenhouse gases (GHG), and production of significant volumes of waste products [7]. Oil sands are an unconventional oil resource with high viscosity, and thus require more energy to recover, extract, and upgrade into refined products than conventional oil resources [8]. Further, oil sands-derived GHG emissions are generally higher than conventional crude oil-derived emissions per unit produced [9]. 
As Canadian government regulators and corporations have adopted GHG emissions reduction targets, oil sands producers have been increasing production. At the national scale, Canada has developed a set of Nationally Determined Contributions intended to reduce its GHG emissions by 30\% below 2005 levels by 2030 [10] and its Mid-Century Strategy (MCS) proposes reductions of as much as $80 \%$ by 2050 [11]. Internationally, regulations such as California's Low Carbon Fuel Standard (LCFS) and the European Fuel Quality Directive require a 10\% reduction in life cycle greenhouse gas (GHG) emissions from transportation fuels by 2020 [12,13]. GHG emissions from the oil sands industry have increased from $35 \mathrm{Mt}$ in 2005 to $72 \mathrm{Mt}$ in 2016 and are expected to reach $106 \mathrm{Mt}$ by 2030 [14], reflecting a growth in oil production with higher prices. Figure 1 shows the GHG emissions trend in each Canadian economic sector from 1990 to 2016. The oil and gas sector became the largest GHG emitting sector in Canada in 2016 [14], mainly through combustion processes. A detailed profile of energy consumption pathways in the oil sands industry is necessary to identify potential areas of improvement and to monitor progress toward meeting emissions reduction targets.

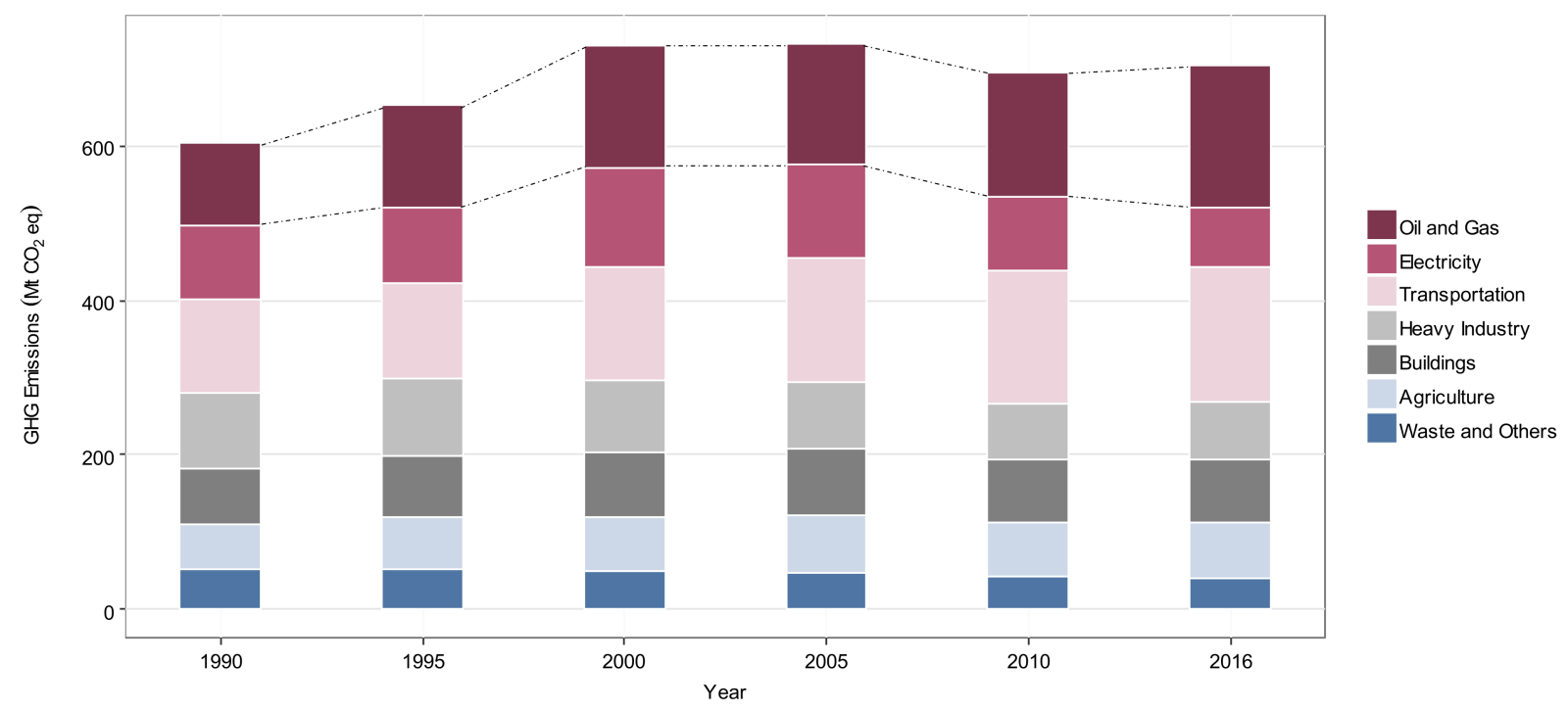

Figure 1. Canadian GHG emissions by economic sector ( $\mathrm{Mt} \mathrm{CO}_{2} \mathrm{eq}$ ) from 1990 to 2016 [14].

To understand the impact of energy activities on economic, climatic and other environmental systems, integrated assessment models (IAMs), energy system models, life-cycle assessments, and similar tools are widely used by scientists, economists, and decision makers. In order to build the energy input-output (I-O) flows of oil sands production through the macroeconomy in these analytical tools, it is important to quantify energy inputs and operating costs of each production process. Although previous studies have investigated technologies and energy consumption in oil sands production, the majority refer to confidential data sources and have inconsistent boundary definitions, preventing their inclusion in open-source model applications. As demonstrated in the following sections, some studies have estimated energy consumption for extraction facilities coupled only with on-site upgrading facilities, while others have estimated energy consumption only for standalone extraction and upgrading facilities. Further, units of measurement for energy consumption and operating costs are inconsistent across the literature. Therefore, this study first reviews recent work published on the oil sands industry, concentrating on energy consumption, greenhouse gas emissions, and operating costs. Based on this information, it then standardizes all values (energy consumption and operating costs) and provides an energy system diagram for the oil sands. Energy and economic coefficients are used to standardize the energy input and cost values (e.g., standard calorific values and currency deflators), and conversion methods are described. Terms including energy consumption and gas emissions in oil sands production refer to the energy consumed and 
gas emitted in oil sands extraction and upgrading. The processes of transport, additional refining, and end-use combustion are not included in the technological boundary. The result is a comprehensive and consistent data set for application to energy system and integrated assessment modeling research. These values can also inform further cost-benefit analyses and environmental impact assessments, and provide data inputs for studies using partial equilibrium models and cost optimization models.

The rest of the paper proceeds as follows. Section 2 summarizes the literature on energy intensity of oil sands production. Section 3 presents emission intensity estimates for oil sands extraction and upgrading technologies. Section 4 provides production cost ranges from various studies. Section 5 synthesizes and standardizes these values and discusses opportunities for future studies.

\section{Energy Efficiency of the Oil Sands Industry}

Oil sands production can be divided into two processes: extraction and upgrading. The extraction process recovers the bitumen portion of the mined oil sands slurry and discards the heavy solids through a gravity separation process. Upgrading transforms extracted bitumen into light oil (synthetic crude oil) through fractionation and chemical treatment, and removes almost all impurities such as sulfur and heavy metals [15]. This section introduces technology options for both processes, and then examines energy input estimates by technology.

\subsection{Energy Efficiency of Extraction}

\subsubsection{Surface Mining}

Surface mining is defined as the extraction of rock or minerals from an open pit. This form of mining is best suited to bitumen deposits no deeper than $50 \mathrm{~m}$ below the ground surface, a criterion that less than $20 \%$ of Alberta's bitumen reserves meet. Although deposits as deep as $75 \mathrm{~m}$ below the surface are possible candidates for surface mining, anything deeper than $75 \mathrm{~m}$ below grade cannot be mined economically [16].

The first stage of surface mining involves the removal of layers of rock, sand, and clay with large excavators and trucks, which use diesel fuel as their primary energy input. Diesel input ranges from 4.4 to 7.1 MJ for each GJ of bitumen produced. Although energy input data for oil sands facilities remain confidential, modeling studies based on those confidential data have provided default figures for energy input. In the FUNNELGHG-OS model developed by Nimana et al. [17], the default diesel input was set as $5.53 \mathrm{MJ} / \mathrm{GJ}$-bitumen, while the GHOST model described by Charpentier et al. [18] included a range of $7-15 \mathrm{~L} / \mathrm{m}^{3}$-bitumen for diesel demand, and used $10 \mathrm{~L} / \mathrm{m}^{3}$-bitumen in its "example scenario" [19]. FUNNEL-GHG-OS is a spreadsheet-based model that computes life-cycle energy consumption and GHG emissions for unit operations in surface-mining and in situ (SAGD) recovery and extraction processes [17]. GHOST is also a spreadsheetbased model that calculates life-cycle GHG emissions from three bitumen recovery and extraction technologies (surface mining, CSS, and SAGD), and two upgrading technologies (delayed coking and hydrocracking) [18]. Its input inventory includes energy consumption parameters [19]. Both models determine GHG emissions and other calculated values per $\mathrm{MJ}$ or $\mathrm{m}^{3}$ of bitumen production for multiple oil sands extraction and upgrading processes, using the range of input coefficients from oil sands projects for well-to-refinery or well-to-wheels system boundaries [19] or based on a bottom-up calculation of energy consumption and GHG emissions for each unit process in oil sands production [17]. Unit process representations require coefficient values for fuel consumption per hour for shovels and trucks, bitumen saturation, oil sands density, slurry temperatures, natural gas use for water heating, and so on [17], or transport distances, type and proportion of diluent used, flared and fugitive hydrocarbon releases, and so on [18]. Note that each study uses different units, which are standardized to consistent units in Section 5.

Once oil sands deposits have been transported to an extraction facility, the second stage of surface mining separates bitumen from sand. Natural gas provides the primary 
energy input for this process, and is used to heat water and generate electricity to operate pumps and floatation vessels. There are three technology options for these processes: no cogeneration, steam turbine cogeneration, and gas turbine cogeneration. No cogeneration is considered a traditional and less efficient mining technology, in which the necessary electricity is imported from the local grid. Its net electricity input is much higher than that of cogeneration technologies. Both cogeneration technologies for oil sands extraction simultaneously produce steam and electricity from natural gas [20], whose consumption depends on the characteristics of the steam/cogeneration used to separate bitumen. According to Nimana et al. [17], all existing oil sands mines incorporate cogeneration facilities because of the high demand for steam and electricity, and the cogeneration capacity continues to expand. By 2022, the installed cogenerating capacity is expected to satisfy on-site power demands and produce a surplus of $18 \%$ for export to the local electricity grid [17].

Two modeling studies have provided average energy input figures for surface mining. The GHOST model input inventory included only the natural gas input for mining without cogeneration (20-80 $\mathrm{m}^{3} / \mathrm{m}^{3}$-bitumen); the electricity input for cogeneration was evaluated through gas turbine efficiencies and co-produced electricity, although numerical values were not provided [19]. In the FUNNEL-GHG-OS model [17], the net electricity input to the no cogeneration technology ranged from 1.8 to $2.1 \mathrm{kWh} / \mathrm{GJ}$-bitumen and natural gas input ranged from 52.7 to $74.1 \mathrm{MJ} / \mathrm{GJ}$-bitumen. For steam turbine cogeneration, the natural gas input was slightly higher than the no cogeneration technology, but the electricity demand was much lower because of the on-site electricity generation. Net electricity input ranged from 0.3 to $0.5 \mathrm{kWh} / \mathrm{GJ}$-bitumen and natural gas input ranged from 61.7 to 86.4 MJ/GJ-bitumen. For gas turbine cogeneration, net electricity input ranged from 0.2 to $1.3 \mathrm{kWh} / \mathrm{GJ}$-bitumen and natural gas input ranged from 64.2 to $78.2 \mathrm{MJ} / \mathrm{GJ}$-bitumen. Because cogeneration technologies create fewer GHG emissions than grid-supplied electricity, which contains a significant fraction of coal-fired generation, they help to reduce overall emissions from oil sands mining. Detailed emission reduction impacts are discussed in Section 3.

\subsubsection{In Situ Production}

Prior to the introduction of a technology that economically extracts bitumen from deeper oil sands, surface mining was the only method available. Deeper extraction became possible when Imperial Oil introduced in situ extraction techniques in the 1980s [21], which now permit production of the $80 \%$ of reserves inaccessible to surface mining. With subsequent technological advancements, in situ facilities can now be installed relatively inexpensively with reduced engineering and construction risks, and a smaller surface footprint. As a result, in situ production has increased about 400-fold from 1975 to 2015, and is expected to surpass production from surface mining in the next few years [21].

There are two commonly applied thermal in situ techniques: Cyclic Steam Stimulation (CSS), which uses a single wellbore for steam injection and oil production, and Steam Assisted Gravity Drainage (SAGD), which uses two wellbores for continuous steam injection and bitumen production. CSS requires the injection of high-pressure steam through the single wellbore into an oil sands deposit over several weeks to fully saturate it. After soaking for days to weeks in the hot, pressurized deposit, its eventual cooling drives oil up to the surface. Oil production can then last several weeks [22]. In a SAGD facility, the two horizontal wells - the injection well and the producing well-are drilled into an oil sands deposit at depths of 80 to $1000 \mathrm{~m}$, one well a few meters above the other [22]. High pressure steam is continuously injected into the upper injection well to heat the surrounding bitumen, causing it to liquefy and flow to the lower producing well. It is then pumped to the surface and sent to an upgrading plant, where the bitumen and water are separated. The recovered water is treated and recycled. SAGD operation is continuous, allowing for much higher production rates than CSS and greater bitumen recovery (nearly $60 \%$ ) in most cases [22], and has a significantly higher production capacity than CSS in 
Alberta [23]. In situ technologies have allowed a significant increase in bitumen production from the oil sands with reduced additional land disturbance.

SAGD uses natural gas to generate process steam and electricity to drive the pumps and evaporator [22]. The local grid satisfies the electricity requirements-which are between 1.2 and $3.5 \mathrm{kWh} / \mathrm{GJ}$-bitumen—of traditional SAGD applications. A more efficient approach employed by almost all recent SAGD operations uses a gas turbine to generate on-site electricity [24]. By 2022, the cogenerating capacity (the maximum electric output of a co-generator) for SAGD operations is anticipated to be $3900 \mathrm{MW}$, while the power demand of SAGD itself will be only $3200 \mathrm{MW}$ [25], yielding a surplus of electricity. The cogenerated electricity ranges from 17.2 to $21.7 \mathrm{kWh} / \mathrm{GJ}$-bitumen. Because cogeneration technologies require electricity input to treat the water from the evaporator before recycling for steam production, the net electricity input is actually higher than for the traditional technology, which ranges from 16.0 to $18.2 \mathrm{kWh} / \mathrm{GJ}$-bitumen. However, because co-generated electricity is produced with natural gas, its emission factor is lower than the electricity purchased from the local grid, part of which is currently produced from coal [26]. Hence, cogeneration technology produces lower greenhouse gas emissions than traditional SAGD [17,27]. This will shift in the coming years as Alberta plans to phase out coal-fired electricity generation by 2030 [28], replacing coal capacity with natural gas and renewable sources. Detailed carbon footprints for both technologies are discussed in Section 3.

\subsection{Energy Efficiency of Upgrading}

Upgrading is a process that transforms extracted crude bitumen into light oil. Crude bitumen production from Alberta's oil sands was almost 1.9 million bpd in 2012, 54\% of which was upgraded to synthetic crude oil, while the remainder (diluted bitumen, or "dilbit") was delivered to international upgraders [29]. Upgrading involves two processing stages. Primary upgrading increases the hydrogen to carbon ratio either by rejecting carbon or adding hydrogen. Secondary upgrading removes impurities such as sulfur, nitrogen, and metals released by primary upgrading and eventually achieves a sulfur content below $0.5 \%$ in the upgraded products [30]. Two upgrading technologies are widely used in the oil sands industry to increase the hydrogen to carbon ratio: delayed coking (rejecting carbon) and hydroconversion (adding hydrogen). Hydroconversion requires more energy but produces more $\mathrm{SCO}$ (synthetic crude oil).

\subsubsection{Delayed Coking}

In the delayed coking process, cokers (oil refinery processing units) operate at high temperatures of about $500{ }^{\circ} \mathrm{C}$ and relatively low pressures to thermally crack bitumen residues into light hydrocarbons (naphtha, kerosene, gas oils), which leave the coker drum as vapors and leave behind a solid concentrated residue, called petroleum coke [15]. Delayed coking processes consume a combination of steam, natural gas, fuel gas, and/or electricity [31].

In the FUNNEL-GHG-OS model [29], energy consumption of delayed coking was estimated as $3.34 \mathrm{GJ}$ to upgrade $1 \mathrm{~m}^{3}$ of bitumen, with $42 \%$ of the total energy required for hydrogen production. Nimana et al. [29] also concluded that $54 \%$ of the energy demand of delayed coking was met through combustion of the fuel gas produced in the plant, while the remainder was fueled by about $47 \mathrm{~m}^{3}$ of natural gas per $1 \mathrm{~m}^{3}$ of bitumen. The default electricity demand in the FUNNEL-GHG-OS model was set to $51.9 \mathrm{kWh} / \mathrm{m}^{3}$ of bitumen. In the GHOST model, energy consumption was calculated on a final production (SCO) basis. The electricity demand for delayed coking (no cogeneration) was about $40-70 \mathrm{kWh} / \mathrm{m}^{3}-\mathrm{SCO}$ and natural gas demand was $95-115 \mathrm{~m}^{3} / \mathrm{m}^{3}-\mathrm{SCO}$ [19], while the cogeneration energy inputs were not discussed.

\subsubsection{Hydroconversion}

As an alternative to delayed coking, hydroconversion cracks larger heavy bitumen molecules into smaller, more-valuable molecules by adding hydrogen in the presence of a 
catalyst [16]. Hydrogen production is an energy-intensive process [28], using approximately $70 \%$ of the total energy required by hydroconversion [29]. This higher hydrogen requirement relative to delayed coking results in higher energy consumption of approximately $6.87 \mathrm{GJ}$ to upgrade $1 \mathrm{~m}^{3}$ of bitumen [27]. The fuel gas requirement of hydroconversion is about $22 \%$ of the total energy demand, a significantly lower value than for delayed coking. However, to upgrade $1 \mathrm{~m}^{3}$ of bitumen, hydroconversion has higher natural gas consumption and electricity demand of $157 \mathrm{~m}^{3}$ and $84.9 \mathrm{kWh} / \mathrm{m}^{3}$, respectively. Unlike delayed coking, hydroconversion does not reject carbon and therefore produces a higher volume of SCO. Specifically, volume yields increase from $78-94 \%$ for delayed coking to $95-106 \%$ for hydroconversion $[18,19]$. In the no cogeneration pathway of the GHOST model, electricity demand for hydroconversion was around $85-130 \mathrm{kWh} / \mathrm{m}^{3}-\mathrm{SCO}$, which was higher than for delayed coking, while natural gas demand was $55-105 \mathrm{~m}^{3} / \mathrm{m}^{3}-\mathrm{SCO}$, lower than for delayed coking [19]. Table 1 summarizes the energy input values from various literature sources. The "default" and "example scenario" values are used to create an energy input-output flow in Section 5.

Table 1. Summary of energy input by oil sands technology.

\begin{tabular}{|c|c|c|c|c|c|c|c|c|c|c|c|}
\hline \multirow{2}{*}{ Energy } & \multirow{2}{*}{ Technology } & \multicolumn{3}{|c|}{ Nimana et al. [17] } & \multicolumn{2}{|c|}{ Nimana et al. [29] } & \multicolumn{3}{|c|}{ Bergerson et al. [19] } & \multicolumn{2}{|c|}{$\begin{array}{c}\text { Charpentier et al. } \\
{[18]}\end{array}$} \\
\hline & & Unit & Range & Default & Unit & Default & Unit & Range & $\begin{array}{l}\text { Example } \\
\text { scenario }\end{array}$ & Unit & Range \\
\hline Diesel & Surface mining & $\begin{array}{l}\text { MJ/GJ- } \\
\text { bitumen }\end{array}$ & $4.4-7.1$ & 5.53 & & & $\mathrm{~L} / \mathrm{m}^{3}$ & $7-15$ & 10 & & \\
\hline \multirow[t]{9}{*}{$\begin{array}{l}\text { Natural } \\
\text { gas }\end{array}$} & $\begin{array}{l}\text { Surface mining } \\
\text { (no cogen.) }\end{array}$ & $\begin{array}{l}\text { MJ/GJ- } \\
\text { bitumen }\end{array}$ & $52.7-74.1$ & 61.3 & & & $\mathrm{~m}^{3} / \mathrm{m}^{3}$ & $20-80$ & 50 & & \\
\hline & $\begin{array}{l}\text { Surface mining } \\
\text { (steam } \\
\text { turbine cogen.) }\end{array}$ & $\begin{array}{l}\text { MJ/GJ- } \\
\text { bitumen }\end{array}$ & $61.7-86.4$ & 72.0 & & & & & & & \\
\hline & $\begin{array}{c}\text { Surface mining } \\
\text { (gas } \\
\text { turbine cogen.) }\end{array}$ & $\begin{array}{l}\text { MJ/GJ- } \\
\text { bitumen }\end{array}$ & $64.2-78.2$ & 71.8 & & & & & & & \\
\hline & $\begin{array}{l}\text { SAGD } \\
\text { (no cogen.) }\end{array}$ & $\begin{array}{l}\text { MJ/GJ- } \\
\text { bitumen }\end{array}$ & $123.7-385.2$ & 148.2 & & & & & & & \\
\hline & $\begin{array}{c}\text { SAGD (gas } \\
\text { turbine cogen.) }\end{array}$ & $\begin{array}{l}\text { MJ/GJ- } \\
\text { bitumen }\end{array}$ & $228.5-462.7$ & 247.8 & & & & & & & \\
\hline & $\begin{array}{l}\text { Delayed coking } \\
\text { (no cogen.) }\end{array}$ & & & & $\begin{array}{l}\mathrm{m}^{3} / \mathrm{m}^{3}- \\
\text { bitumen }\end{array}$ & 40.4 & & & & & \\
\hline & $\begin{array}{l}\text { Delayed coking } \\
\text { (cogen.) }\end{array}$ & & & & $\begin{array}{l}\mathrm{m}^{3} / \mathrm{m}^{3}- \\
\text { bitumen }\end{array}$ & 68.9 & & & & & \\
\hline & $\begin{array}{l}\text { Hydroconversion } \\
\text { (no cogen.) }\end{array}$ & & & & $\begin{array}{l}\mathrm{m}^{3} / \mathrm{m}^{3}- \\
\text { bitumen }\end{array}$ & 147.1 & & & & & \\
\hline & $\begin{array}{l}\text { Hydroconversion } \\
\text { (cogen.) }\end{array}$ & & & & $\begin{array}{l}\mathrm{m}^{3} / \mathrm{m}^{3}- \\
\text { bitumen }\end{array}$ & 197.1 & & & & & \\
\hline \multirow[t]{2}{*}{ Fuel gas } & $\begin{array}{l}\text { Delayed coking } \\
\text { (no cogen.; } \\
\text { cogen.) }\end{array}$ & $\begin{array}{l}\mathrm{kg} / \mathrm{m}^{3}- \\
\text { bitumen }\end{array}$ & & 47.5 & & & & & & & \\
\hline & $\begin{array}{l}\text { Hydroconversion } \\
\text { (no cogen.; } \\
\text { cogen.) }\end{array}$ & $\begin{array}{r}\mathrm{kg} / \mathrm{m}^{3}- \\
\text { bitumen }\end{array}$ & & 39.1 & & & & & & & \\
\hline \multirow[t]{2}{*}{ Total gas } & $\begin{array}{l}\text { Delayed coking } \\
\text { (no cogen.) }\end{array}$ & & & & & & $\begin{array}{l}\mathrm{m}^{3} / \mathrm{m}^{3}- \\
\mathrm{SCO}\end{array}$ & 95-115 & 105 & $\begin{array}{l}\mathrm{m}^{3} / \mathrm{m}^{3}- \\
\mathrm{SCO}\end{array}$ & $95-115$ \\
\hline & $\begin{array}{l}\text { Hydrocracking } \\
\text { (no cogen.) }\end{array}$ & & & & & & $\begin{array}{l}\mathrm{m}^{3} / \mathrm{m}^{3}- \\
\mathrm{SCO}\end{array}$ & 55-115 & 85 & $\begin{array}{l}\mathrm{m}^{3} / \mathrm{m}^{3}- \\
\mathrm{SCO}\end{array}$ & $55-115$ \\
\hline \multirow[t]{5}{*}{$\begin{array}{c}\text { Net } \\
\text { electricity }\end{array}$} & $\begin{array}{l}\text { Surface mining } \\
\text { (no cogen.) }\end{array}$ & $\begin{array}{l}\text { kWh/GJ- } \\
\text { bitumen }\end{array}$ & $1.8-2.1$ & 2.0 & & & & & & & \\
\hline & $\begin{array}{l}\text { Surface mining } \\
\text { (steam } \\
\text { turbine cogen.) }\end{array}$ & $\begin{array}{l}\text { kWh/GJ- } \\
\text { bitumen }\end{array}$ & $0.3-0.5$ & 0.5 & & & & & & & \\
\hline & $\begin{array}{l}\text { Surface mining } \\
\text { (gas turbine } \\
\text { cogen.) }\end{array}$ & $\begin{array}{l}\text { kWh/GJ- } \\
\text { bitumen }\end{array}$ & $0.2-1.3$ & 0.7 & & & & & & & \\
\hline & $\begin{array}{c}\text { SAGD } \\
\text { (no cogen.) }\end{array}$ & $\begin{array}{l}\mathrm{kWh} / \mathrm{GJ}- \\
\text { bitumen }\end{array}$ & $1.2-3.5$ & 1.5 & & & & & & & \\
\hline & $\begin{array}{l}\text { SAGD (gas } \\
\text { turbine cogen.) }\end{array}$ & $\begin{array}{l}\text { kWh/GJ- } \\
\text { bitumen }\end{array}$ & $16.0-18.2$ & 17.9 & & & & & & & \\
\hline
\end{tabular}


Table 1. Cont.

\begin{tabular}{|c|c|c|c|c|c|c|c|c|c|c|c|}
\hline \multirow{2}{*}{ Energy } & \multirow{2}{*}{ Technology } & \multicolumn{3}{|c|}{ Nimana et al. [17] } & \multicolumn{2}{|c|}{ Nimana et al. [29] } & \multicolumn{3}{|c|}{ Bergerson et al. [19] } & \multicolumn{2}{|c|}{$\begin{array}{c}\text { Charpentier et al. } \\
{[18]}\end{array}$} \\
\hline & & Unit & Range & Default & Unit & Default & Unit & Range & $\begin{array}{l}\text { Example } \\
\text { scenario }\end{array}$ & Unit & Range \\
\hline & $\begin{array}{l}\text { Delayed coking } \\
\text { (no cogen.) }\end{array}$ & & & & $\begin{array}{l}\mathrm{kWh} / \mathrm{m}^{3}- \\
\text { bitumen }\end{array}$ & 51.9 & & & & & \\
\hline & $\begin{array}{c}\text { Delayed coking } \\
\text { (cogen.) }\end{array}$ & & & & $\begin{array}{l}\mathrm{kWh} / \mathrm{m}^{3}- \\
\text { bitumen }\end{array}$ & -41.4 & & & & & \\
\hline & $\begin{array}{l}\text { Hydroconversion } \\
\text { (no cogen.) }\end{array}$ & & & & $\begin{array}{l}\mathrm{kWh} / \mathrm{m}^{3}- \\
\text { bitumen }\end{array}$ & 84.9 & & & & & \\
\hline & $\begin{array}{l}\text { Hydroconversion } \\
\text { (cogen.) }\end{array}$ & & & & $\begin{array}{l}\mathrm{kWh} / \mathrm{m}^{3}- \\
\text { bitumen }\end{array}$ & -83 & & & & & \\
\hline \multirow[t]{4}{*}{$\begin{array}{l}\text { Electricity } \\
\text { used }\end{array}$} & $\begin{array}{l}\text { Surface mining } \\
\text { (no cogen.; } \\
\text { cogen) }\end{array}$ & & & & & & $\begin{array}{l}\mathrm{kWh} / \mathrm{m}^{3}- \\
\text { bitumen }\end{array}$ & 50-100 & 60 & & \\
\hline & $\begin{array}{l}\text { SAGD (no } \\
\text { cogen.; cogen) }\end{array}$ & & & & & & & & & $\begin{array}{l}\mathrm{kWh} / \mathrm{m}^{3}- \\
\text { bitumen }\end{array}$ & $45-120$ \\
\hline & $\begin{array}{l}\text { Delayed coking } \\
\text { (no cogen.) }\end{array}$ & & & & & & $\begin{array}{l}\mathrm{kWh} / \mathrm{m}^{3}- \\
\mathrm{SCO}\end{array}$ & $40-70$ & 55 & $\begin{array}{l}\mathrm{kWh} / \mathrm{m}^{3}- \\
\mathrm{SCO}\end{array}$ & $40-70$ \\
\hline & $\begin{array}{l}\text { Hydrocracking } \\
\text { (no cogen.) }\end{array}$ & & & & & & $\begin{array}{l}\mathrm{kWh} / \mathrm{m}^{3}- \\
\mathrm{SCO}\end{array}$ & $85-130$ & 100 & $\begin{array}{l}\mathrm{kWh} / \mathrm{m}^{3}- \\
\mathrm{SCO}\end{array}$ & $85-130$ \\
\hline \multirow[t]{4}{*}{$\begin{array}{c}\text { Total } \\
\text { electricity } \\
\text { produced }\end{array}$} & $\begin{array}{l}\text { Surface mining } \\
\text { (no cogen.; } \\
\text { cogen) }\end{array}$ & & & & & & $\begin{array}{l}\mathrm{kWh} / \mathrm{m}^{3}- \\
\text { bitumen }\end{array}$ & $240-2400$ & 1200 & & \\
\hline & $\begin{array}{c}\text { SAGD (no } \\
\text { cogen.; cogen) }\end{array}$ & & & & & & & & & $\begin{array}{l}\mathrm{kWh} / \mathrm{m}^{3}- \\
\text { bitumen }\end{array}$ & $300-3000$ \\
\hline & $\begin{array}{l}\text { Delayed coking } \\
\text { (cogen.) }\end{array}$ & & & & & & $\begin{array}{l}\mathrm{kWh} / \mathrm{m}^{3}- \\
\mathrm{SCO}\end{array}$ & $220-2200$ & 1100 & $\begin{array}{l}\mathrm{kWh} / \mathrm{m}^{3}- \\
\mathrm{SCO}\end{array}$ & $220-2200$ \\
\hline & $\begin{array}{l}\text { Hydrocracking } \\
\text { (cogen.) }\end{array}$ & & & & & & $\begin{array}{l}\mathrm{kWh} / \mathrm{m}^{3}- \\
\mathrm{SCO}\end{array}$ & $400-4000$ & 2000 & $\begin{array}{l}\mathrm{kWh} / \mathrm{m}^{3}- \\
\mathrm{SCO}\end{array}$ & $400-4000$ \\
\hline
\end{tabular}

\section{Greenhouse Gas Emissions from the Oil Sands Industry}

Extraction and upgrading processes produce the bulk of oil sands' greenhouse gas emissions. Some emissions are also associated with noncombustion processes (venting, flaring, and fugitive emissions) and land use changes. This section first examines emissions estimates by technology, and then describes noncombustion and land use emissions. Several modeling studies have estimated gas emission figures based on confidential operating data. Since those data are not publicly available, this section relies on the model estimates.

\subsection{Greenhouse Gas Emissions from Extraction}

\subsubsection{Surface Mining}

The FUNNEL-GHG-OS model [17] included an emissions intensity estimate for surface mining without cogeneration of $230-302 \mathrm{~kg}-\mathrm{CO}_{2} / \mathrm{m}^{3}$-bitumen. Results were produced for cases both with and without cogeneration (using either steam or gas turbines). Since coal-based electricity from the local grid has a higher $\mathrm{CO}_{2}$ intensity, facilities with cogeneration technologies can reduce GHG emissions when they export electricity to the local grid. In particular, gas turbines as compared with steam turbines export more electricity and thus offer greater emission reductions: $12-30 \%$ greater reduction than without cogeneration. In comparison with previous literature and models, Nimana et al. [17] estimated that their FUNNEL-GHG-OS model results lay within the range presented by the GREET model, of $206.2 \mathrm{~kg}-\mathrm{CO}_{2} / \mathrm{m}^{3}$-bitumen [27], and work by Jacobs [32], which uses $297.54 \mathrm{~kg}-\mathrm{CO}_{2} / \mathrm{m}^{3}$-bitumen. Other studies $[9,19,33,34]$ give different emission profiles, because of different technology boundaries and assumptions. For example, the GHGenius model [35] considered cogeneration in surface mining operations while the GREET model [27] did not.

GHOST, the first oil sands life cycle-based model, calculated both direct and indirect emissions [19]. Its estimated surface mining emissions ranged between 2.5 and $8.9 \mathrm{~g}-\mathrm{CO}_{2} \mathrm{eq} / \mathrm{MJ}-\mathrm{bitumen}$. Direct emissions in the cogeneration case were estimated at between 2.3 and $7.2 \mathrm{~g}-\mathrm{CO}_{2} \mathrm{eq} / \mathrm{MJ}$-bitumen (low and high scenarios, respectively), corresponding to $89-92 \%$ of total emissions. In the no cogeneration case, direct emissions were estimated to lie between 1.6 and $5.9 \mathrm{~g}-\mathrm{CO}_{2} \mathrm{eq} / \mathrm{MJ}$-bitumen, constituting $54-67 \%$ of total 
emissions. Importantly, the emission profiles from the FUNNEL-GHG-OS model and the GHOST model differed significantly because of disparate assumptions about cogenerated power. The GHOST model assumed that the amount of electricity produced perfectly matched on-site demand, while the FUNNEL-GHG-OS model assumed surplus electricity was sold to the local grid. Assumptions related to cogenerated power in oil sands projects have a significant impact on modeled overall emission pathways [36].

\subsubsection{In Situ Production}

The majority of the GHG emissions from SAGD come from steam generation. In the FUNNEL-GHG-OS model, the $\mathrm{CO}_{2}$ emissions from SAGD operations without cogeneration ranged from 562 to $1384 \mathrm{~kg} / \mathrm{m}^{3}$-bitumen, while gas turbine cogeneration reduced emissions to between 327 and $931 \mathrm{~kg} / \mathrm{m}^{3}$-bitumen. Natural gas was the dominant source of emissions. In a no cogeneration case, the natural gas-derived emissions share was $70 \%$. The second largest contributor, electricity, was responsible for about $6-20 \%$ of the total emissions. GHOST model results showed that emissions from the solution gas coproduced on-site (natural gas produced along with oil from oil sands wells) played a minor role in the total SAGD emissions [18].

\subsection{Greenhouse Gas Emissions from Upgrading}

Greenhouse gas emissions from upgrading come from heat processing (mainly natural gas), hydrogen production, and electricity generation, either from cogeneration or import from the local grid. The FUNNEL-GHG-OS model [29] estimated emissions for delayed coking and hydroconversion separately, with total GHG emissions of $240 \mathrm{~kg}-\mathrm{CO}_{2} \mathrm{eq} / \mathrm{m}^{3}$ bitumen in delayed coking and $433 \mathrm{~kg}-\mathrm{CO}_{2} \mathrm{eq} / \mathrm{m}^{3}$-bitumen in hydroconversion, both with no cogeneration. The higher energy demand for hydrogen production resulted in higher emissions from delayed coking. Natural gas combustion accounted for $81 \%$ and $82.7 \%$ of the total emissions in delayed coker upgrading and hydroconversion, respectively.

When cogeneration units are employed, natural gas consumption increases in both upgrading configurations. However, because natural gas-based cogenerated electricity replaces more carbon-intensive grid power, the net emissions actually decrease by $13 \%$ in delayed coker upgrading and $16 \%$ in hydroconversion upgrading. Nimana et al. [29] stated that these values were also within $10 \%$ of the emissions values reported by Jacobs [32]. In the GHOST model, the emissions associated with upgrading bitumen to SCO ranged from 6.4 to $16.7 \mathrm{~g}-\mathrm{CO}_{2} \mathrm{eq} / \mathrm{MJ}-\mathrm{SCO}$ [19]. In no cogeneration cases, grid electricity-based emissions could contribute up to $3.2 \mathrm{~g}-\mathrm{CO}_{2} \mathrm{eq} / \mathrm{MJ}-\mathrm{SCO}$. Table 2 summarizes estimated $\mathrm{CO}_{2}$ emissions by technology from four modeling studies.

Table 2. Summary of $\mathrm{CO}_{2}$ emission by oil sands technology.

\begin{tabular}{|c|c|c|c|c|c|c|c|c|c|c|c|}
\hline \multirow{2}{*}{ Technology } & \multicolumn{3}{|c|}{ Nimana et al. [17] } & \multicolumn{2}{|c|}{ Nimana et al. [29] } & \multicolumn{3}{|c|}{ Bergerson et al. [19] } & \multicolumn{3}{|c|}{ Charpentier et al. [18] } \\
\hline & Unit & Range & Default & Unit & Default & Unit & Low & High & Unit & Low & High \\
\hline $\begin{array}{l}\text { Surface mining } \\
\text { (no cogen.) }\end{array}$ & $\begin{array}{l}\text { g- } \mathrm{CO}_{2} / \mathrm{MJ}- \\
\text { bitumen }\end{array}$ & $5.4-7.4$ & 6.3 & & & $\begin{array}{l}\text { g- } \mathrm{CO}_{2} / \mathrm{MJ}- \\
\text { bitumen }\end{array}$ & 2.9 & 8.9 & & & \\
\hline $\begin{array}{l}\text { Surface mining } \\
\text { (cogen.) }\end{array}$ & & & & & & $\begin{array}{c}\text { g- } \mathrm{CO}_{2} / \mathrm{MJ}- \\
\text { bitumen }\end{array}$ & 2.5 & 8.1 & & & \\
\hline $\begin{array}{l}\text { Surface mining } \\
\text { (steam } \\
\text { turbine cogen.) }\end{array}$ & $\begin{array}{c}\text { g- } \mathrm{CO}_{2} / \mathrm{MJ}- \\
\text { bitumen }\end{array}$ & $4.7-6.8$ & 5.7 & & & & & & & & \\
\hline $\begin{array}{l}\text { Surface mining } \\
\text { (gas } \\
\text { turbine cogen.) }\end{array}$ & $\begin{array}{c}\text { g- } \mathrm{CO}_{2} / \mathrm{MJ}- \\
\text { bitumen }\end{array}$ & $4.6-4.9$ & 4.9 & & & & & & & & \\
\hline $\begin{array}{c}\text { SAGD } \\
\text { (no cogen.) }\end{array}$ & $\begin{array}{l}\text { g- } \mathrm{CO}_{2} / \mathrm{MJ}- \\
\text { bitumen }\end{array}$ & $9.3-28.9$ & 11.3 & & & & & & $\begin{array}{c}\text { g-CO } \mathrm{CO}_{2} / \mathrm{MJ}- \\
\text { bitumen }\end{array}$ & 9.5 & 16.1 \\
\hline SAGD (cogen.) & & & & & & & & & $\begin{array}{c}\mathrm{g}-\mathrm{CO}_{2} / \mathrm{MJ}- \\
\text { bitumen }\end{array}$ & 9.0 & 13.8 \\
\hline $\begin{array}{l}\text { SAGD (gas } \\
\text { turbine cogen.) }\end{array}$ & $\begin{array}{c}\text { g- } \mathrm{CO}_{2} / \mathrm{MJ}- \\
\text { bitumen }\end{array}$ & $5.8-20.1$ & 18.4 & & & & & & & & \\
\hline $\begin{array}{l}\text { Delayed coking } \\
\text { (no cogen.) }\end{array}$ & & & & $\begin{array}{l}\mathrm{kg}-\mathrm{CO}_{2} \mathrm{eq} / \mathrm{m}^{3}- \\
\text { bitumen }\end{array}$ & 240.3 & g- $\mathrm{CO}_{2} / \mathrm{MJ}-\mathrm{SCO}$ & 7.8 & 15.0 & g- $\mathrm{CO}_{2} / \mathrm{MJ}-\mathrm{SCO}$ & 7.8 & 15.0 \\
\hline $\begin{array}{l}\text { Delayed coking } \\
\text { (cogen.) }\end{array}$ & & & & $\begin{array}{c}\mathrm{kg}-\mathrm{CO}_{2} \mathrm{eq} / \mathrm{m}^{3}- \\
\text { bitumen }\end{array}$ & 208.6 & g- $\mathrm{CO}_{2} / \mathrm{MJ}-\mathrm{SCO}$ & 7.4 & 14.2 & g- $\mathrm{CO}_{2} / \mathrm{MJ}-\mathrm{SCO}$ & 7.4 & 14.2 \\
\hline
\end{tabular}


Table 2. Cont.

\begin{tabular}{|c|c|c|c|c|c|c|c|c|c|c|c|}
\hline \multirow{2}{*}{ Technology } & \multicolumn{3}{|c|}{ Nimana et al. [17] } & \multicolumn{2}{|c|}{ Nimana et al. [29] } & \multicolumn{3}{|c|}{ Bergerson et al. [19] } & \multicolumn{3}{|c|}{ Charpentier et al. [18] } \\
\hline & Unit & Range & Default & Unit & Default & Unit & Low & High & Unit & Low & High \\
\hline $\begin{array}{l}\text { Hydroconversion } \\
\text { (no cogen.) }\end{array}$ & & & & $\underset{\text { bitumen }}{\mathrm{kg}-\mathrm{CO}_{2} \mathrm{eq} / \mathrm{m}^{3}-}$ & 433.4 & & & & & & \\
\hline $\begin{array}{l}\text { Hydroconversion } \\
\text { (cogen.) }\end{array}$ & & & & $\begin{array}{c}\mathrm{kg}-\mathrm{CO}_{2} \mathrm{eq} / \mathrm{m}^{3}- \\
\text { bitumen }\end{array}$ & 365 & & & & & & \\
\hline $\begin{array}{l}\text { Hydrocracking } \\
\text { (no cogen.) }\end{array}$ & & & & & & g- $\mathrm{CO}_{2} / \mathrm{MJ}-\mathrm{SCO}$ & 7.1 & 16.7 & g- $\mathrm{CO}_{2} / \mathrm{MJ}-\mathrm{SCO}$ & 7.1 & 16.7 \\
\hline $\begin{array}{l}\text { Hydrocracking } \\
\text { (cogen.) }\end{array}$ & & & & & & g- $\mathrm{CO}_{2} / \mathrm{MJ}-\mathrm{SCO}$ & 6.4 & 15.5 & $\mathrm{~g}-\mathrm{CO}_{2} / \mathrm{MJ}-\mathrm{SCO}$ & 6.4 & 15.5 \\
\hline
\end{tabular}

\subsection{Noncombustion and Land Use Associated Emissions}

A number of oil sands bitumen-extraction stages release greenhouse gases. Noncombustion process emissions include venting, flaring, and fugitive (VFF) emissions. Based on in situ measurements of emissions from the main oil sands tailings ponds across the Athabasca oil sands region, thickened tailings and fresh froth treatment tailings were associated with higher volatile organic compound emissions, while older tailings ponds emitted higher methane concentrations through the development of methanogenesis [7]. Environment and Climate Change Canada reported approximately $3 \mathrm{~g}-\mathrm{CO}_{2} / \mathrm{MJ}$-bitumen from mining and approximately $1 \mathrm{~g}-\mathrm{CO}_{2} / \mathrm{MJ}$-bitumen from in situ production [37]. Land use change emissions are associated with biomass disturbance and oxidation due to land clearing, soil disturbance, and peat disturbance. For mining operations, these emissions are generally smaller than the VFF emissions, with a representative value of $1.4 \mathrm{~g}-\mathrm{CO}_{2} / \mathrm{MJ}-$ bitumen, within a range of 1.0 to $2.3 \mathrm{~g}-\mathrm{CO}_{2} / \mathrm{MJ}$-bitumen produced [38]. Among the land use change emissions, peat disturbance has the largest impact [38]. Compared to surface mining, in situ operations have minor land use emissions [30].

\section{Costs in the Oil Sands Industry}

The cost structure of the oil sands industry has been subject to much analysis in recent years, particularly in terms of the financial implications of climate policies for oil sands production. Some studies [39] have forecasted short- and long-term crashes in the price of oil. However, supply costs are expected to decrease over time with technological improvements, which may allow some plants to remain economically viable for several decades. This section compiles and analyzes data related to oil sands costs at the plant gate, which exclude transportation and blending costs.

Reported operating costs for oil sands facilities vary, because of the different extraction technologies employed, differences in natural gas prices and carbon taxes, as well as export restrictions and market competition. Overall estimates for operating costs range from USD 7.04 to USD 16.43 per barrel of bitumen and USD 21.12 to USD 25.81 per barrel of synthetic crude oil [40] (2015 U.S. dollars). Supply costs for surface mining range from USD 16.42 to USD 28.15 and USD 41.15 to USD 46.93 per barrel for bitumen and synthetic crude oil, respectively. These values are reported as a price per barrel at the plant gate, and include operating costs, capital costs, taxes, royalties, and the rate of return on investment. SAGD operations are estimated to be economic between USD 36.24 and USD 42.28 per barrel [40]. All values here are reported in 2015 US dollars to support broader application. Currency conversions and corrections for inflation were conducted using the World Bank GDP deflator [41] and the USDA International Macroeconomic Data Set was used to resolve currency exchange rates for 2018.

\subsection{Extraction Costs}

\subsubsection{Surface Mining Costs}

Méjean and Hope [42] summarized published values for the supply and operating costs of oil sands facilities. Operating costs for surface mining extraction ranged from USD 7.25 to USD 12.08 and the total supply costs at the plant gate were between USD 14.49 and USD 20.54 per barrel of bitumen. Plants with integrated mining and upgrading phases 
that produce synthetic crude had operating cost ranges from USD 14.49 to USD 21.74 and total supply costs of USD 21.74 to USD 39.86 per barrel of SCO. However, after 2014, new carbon policies, logistical restrictions related to transport of bitumen and SCO, and low global oil reserves [43] raised supply costs to USD 105.19 per barrel of SCO at the gate of an integrated mining and upgrading plant and to USD 110.67 per barrel equivalent on the West Texas Intermediate (WTI) benchmark [44].

A recent Canadian Energy Research Institute report [45] stated that the supply costs at the plant gate for mining operations without attached upgrading were USD 69.02 per barrel, with an increase to USD 74.91 per barrel after blending and transportation to the US market. The largest contributors among the supply costs were fixed capital (initial and sustaining; $48.1 \%)$, royalties $(18.6 \%)$, income taxes $(7.1 \%)$, natural gas $(3.8 \%)$, and other miscellaneous operating costs including electricity $(21.2 \%)$. The small remainder was comprised of emissions compliance costs, operating working capital, and abandonment costs.

\subsubsection{SAGD Costs}

The typical lifespan of a SAGD plant and upgrading facilities is 25 years. Plants with cogeneration have lower production costs because of the revenue generated from the produced electricity [46]. Méjean and Hope [42] investigated unit supply costs at the plant gate for in situ bitumen production. For cyclic steam stimulation (CSS) production of bitumen, they found operating costs to range from USD 7.25 to USD 14.49 and supply costs to range from USD 12.08 to USD 24.16. Operating costs for CSS production of SCO, when coupled with an upgrading phase, varied from USD 5.44 to USD 8.46. Supply costs for CSS production of SCO were not provided. For SAGD technologies, operating costs varied from USD 6.04 to USD 14.49 and the total supply cost varied from USD 8.46 to USD 21.74 per barrel of bitumen. The operating cost for a SAGD plant coupled with an upgrading component ranged from USD 4.23 to USD 8.46 per barrel of SCO. Millington et al. [44] estimated a supply cost for SAGD of USD 42.66 per barrel at the plant gate, which increased to USD 59.86 per barrel with adjustments after blending and transportation, to the WTI equivalent supply costs. The majority of the supply costs came from natural gas (13.6\%), royalties $(16.5 \%)$, fixed capital $(44.4 \%)$ and other operating costs, such as electricity $(17.4 \%)$. The remaining costs were related to operating capital, income taxes, emissions regulations compliance, and abandonment and reclamation of project sites.

Recently, a number of new projects have been proposed for new oil sands extraction projects and pipelines, called greenfield facilities [40], as well as expansions of current projects. Millington [4] explored cost scenarios for proposed expansion and greenfield projects and found that supply costs at a greenfield SAGD plant gate were USD 32.39 per barrel of bitumen, while an expansion scenario had costs of USD 21.49 per barrel. The proposed expansion scenario incorporated both production expansion and currently proposed pipelines. After blending and transportation to the US market, supply costs for both the greenfield and expansion scenarios were expected to increase to USD 57.12 per barrel and USD 48.97 per barrel, respectively. The costs of both scenarios were considered economically viable based on projections of the market price.

\subsection{Upgrading Costs}

Bitumen is commonly diluted and sold for further processing either elsewhere in Canada or in the US, since many production sites are not equipped with upgrading facilities. The cost for upgrading bitumen to SCO varies from USD 26.57 to USD 30.20 per barrel [42], while costs for a standalone upgrader are estimated as USD 39.82 per barrel [44].

Sapkota et al. [46] presented costs for a number of alternative upgrading technologies, including hydroconversion and delayed coking both with and without cogeneration, of USD 39.16 and USD 37.91 for hydroconversion, and USD 28.96 and USD 26.44 for delayed coking. Initial capital and O\&M costs were the two major components of the upgrading cost. Further, SCO production through hydroconversion was more expensive because of higher capital costs and greater consumption of natural gas and electricity. These costs 
have decreased over time: according to the National Energy Board [40], the average supply cost per barrel of SCO was around USD 45.75 in 2006.

\section{Discussion}

Figure 2 summarizes energy inputs and operating costs according to oil sands technology. The energy inputs indicated in Figure 2 are the best values available from modeling studies (Table 1). Most of the energy inputs were based on the default parameter settings of the FUNNEL-GHG-OS model, since it had the most detailed oil sands production process among all models reviewed. However, where default values in FUNNEL-GHG-OS were out of the range suggested by other models, an average value from all models was used in Figure 2. On the cost side, the medians of cost ranges suggested by Méjean and Hope [42] were used in Figure 2. Standard calorific values of energy inputs were used to convert different units in Table 1, while World Bank GDP deflator [41] and the USDA International Macroeconomic Data Set were used to convert cost values. The energy demands in terms of exajoules of energy input per exajoule of bitumen produced (EJ/EJ-bitumen) and the operating costs (2015 USD/GJ-bitumen) were converted from the data introduced in Sections 2 and 4 to consistent technology boundaries and energy units. Energy inputs include natural gas, diesel, electricity, and fuel gas. The electricity inputs for cogeneration technologies are net values that incorporate both the total demand and surplus power. Further, while cogenerated power cannot fully satisfy the total electricity demand of extraction technologies, upgrading technologies can generate surplus power on-site for export to the local grid. Therefore, negative electricity inputs represent the export of excess electricity. Finally, the energy inputs and operating costs of upgrading technologies are additive values and do not include the quantities needed in the preceding extraction processes. Energy conversion coefficients were taken from IEA [47] and as described in Section 4.

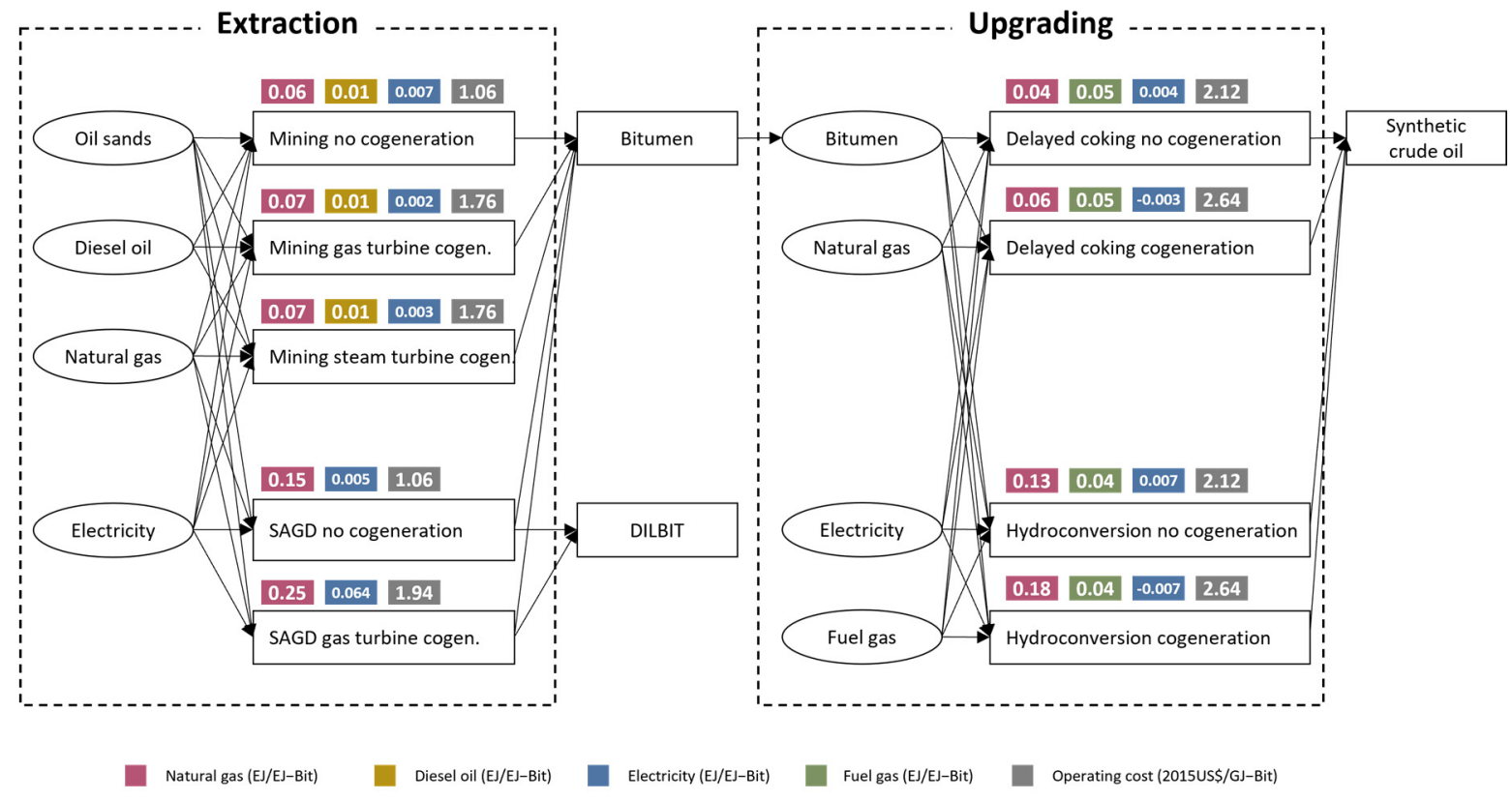

Figure 2. Energy inputs and operating costs in oil sands projects.

The existing literature provides energy input and associated $\mathrm{CO}_{2}$ emission of each stage in the oil sands industry and explains uncertainties. Despite differences in technology boundaries, the literature clearly indicates that emissions associated with steam and electricity generation are the largest contributors to the total $\mathrm{CO}_{2}$ emissions from oil sands extraction. In upgrading, the bulk of the energy demand is associated with hydrogen production, therefore also contributing to most of its emissions. Natural gas is used for both extraction and upgrading activities; therefore, its replacement by renewable energy (e.g., nuclear, geothermal, biomass, and wind) would reduce carbon emissions 
from oil sands production. For example, hydrogen production with renewables, such as wind, could significantly reduce the GHG footprint of oil sands upgrading processes [48]. Similarly, carbon capture and storage (CCS) presents a lower carbon alternative for oil sands production; however, initial costs and other factors (e.g., technological uncertainty) may prevent wide-scale implementation in the near future [49]. Using energy inputs for modeling provides a bottom-up approach, consistent with the way oil and gas facilities report their greenhouse gas emissions. A top-down approach by Liggio et al. [50] used aircraft to measure the $\mathrm{CO}_{2}$ emission levels at four oil sands facilities in the Athabasca region of northeastern Alberta based on atmospheric observations. They suggested that $\mathrm{CO}_{2}$ emission intensities for oil sands facilities are 13-123\% larger than those estimated using publicly available data because of technological uncertainty and emission factors. When using the energy input data in Figure 2 to model the oil sands industry, such uncertainties should be considered.

\section{Conclusions}

This study has reviewed the literature associated with historical and current technology profiles for oil sands production. No studies to date have provided a future vision of technology-specific energy consumption, GHG emissions, and supply cost projections. Both international organizations and the Canadian government have set long-term targets for GHG emission reductions, and projections of future emissions from oil sands production are important for evaluating progress toward meeting these targets. A range of models, such as partial equilibrium models and cost optimization models, are available or being developed to forecast future oil sands production and associated emissions. This paper provides key input to facilitate such modeling work. The numbers listed in Figure 2 can be used by oil sands companies and government ministries for evaluating environmental impacts of the oil sands industry.

Author Contributions: Conceptualization, R.X., M.T.B. and E.G.R.D.; data curation, R.X. and D.V.C.; writing—original draft preparation, R.X., D.V.C.; writing—review and editing, R.X., D.V.C., E.J.A., M.T.B. and E.G.R.D.; visualization, R.X.; supervision, E.G.R.D.; project administration, M.T.B. and E.G.R.D.; funding acquisition, E.G.R.D. All authors have read and agreed to the published version of the manuscript.

Funding: This research was funded by Future Energy Systems of the Canada First Research Excellence Fund, project T13-02. The Joint Global Change Research Institute authors acknowledge support from Environment and Climate Change Canada (ECCC) under contract number 3000682645.

Institutional Review Board Statement: Not applicable.

Informed Consent Statement: Not applicable.

Acknowledgments: The authors thank Candelaria Bergero and Muhammad-Shahid Siddiqui for their helpful advice and comments.

Conflicts of Interest: The authors declare no conflict of interest. The funders had no role in the design of the study; in the collection, analyses, or interpretation of data; in the writing of the manuscript, or in the decision to publish the results.

\section{References}

1. Natural Resources Canada. Available online: https://www.nrcan.gc.ca/energy-facts/crude-oil-facts/20064 (accessed on 3 July 2021).

2. Canadian Association of Petroleum Producers. Available online: http://www.capp.ca/publications-and-statistics/statistics (accessed on 21 May 2020).

3. Canadian Association of Petroleum Producers. Available online: http://www.capp.ca/publications-and-statistics/crude-oilforecast (accessed on 15 July 2020).

4. Millington, D. Canadian Oil Sands Supply Costs and Development Projects (2018-2038). Canadian Energy Research Institute. Available online: https:/ / ceri.ca/studies/ canadian-oil-sands-supply-costs-and-development-projects-2018--2038 (accessed on 13 January 2020). 
5. Rafaei, M.; Adeyemo, T.; Bararpour, T.; Bartholameuz, E.; Hossain, N.; Millington, D.; Mikhail, M.; Rahmanifard, H. Economic Recovery Pathways for Canada's Energy Industry: Part 2-Canadian Crude Oil and Natural Gas. Canadian Energy Research Institute. Available online: https:/ / ceri.ca/assets/files/Study_192B_Full_Report.pdf (accessed on 4 August 2021).

6. Petersen, R.; Sizer, N. Tar Sands Threaten World's largest Boreal Forest. World Resources Institute. Available online: http: //wri.org/blog/2014/07/tar-sands-threaten-world-s-largest-boreal-forest (accessed on 14 March 2021).

7. Small, C.C.; Cho, S.; Hashisho, Z.; Ulrich, A.C. Emissions from oil sands tailings ponds: Review of tailings pond parameters and emission estimates. J. Pet. Sci. Eng. 2015, 127, 490-501. [CrossRef]

8. Brandt, A.R.; Englander, J.; Bharadwaj, S. The energy efficiency of oil sands extraction: Energy return ratios from 1970 to 2010. Energy 2013, 55, 693-702. [CrossRef]

9. Charpentier, A.D.; Bergerson, J.A.; MacLean, H.L. Understanding the Canadian oil sands industry's greenhouse gas emissions. Environ. Res. Lett. 2009, 4, 014005:1-0145005:11. [CrossRef]

10. Environment and Climate Change Canada. Available online: http:/ / www.canada.ca/en/environment-climate-change/services/ climate-change/greenhouse-gas-emissions/second-biennial-report.html (accessed on 19 December 2019).

11. Environment and Climate Change Canada. Available online: https://unfccc.int/files/focus/long-term_strategies/application/ pdf/canadas_mid-century_long-term_strategy.pdf (accessed on 11 July 2021).

12. Ricardo Energy \& Environment. California Low Carbon Fuel Standard. Available online: https:/ / esc-non-prod.s3.eu-west-2. amazonaws.com/2018/10/California-LCFS-Case-Study-FINAL.pdf (accessed on 7 June 2021).

13. European Commission. Available online: http:/ / ec.europa.eu/clima/policies/transport/fuel_en (accessed on 20 August 2020).

14. Environment and Climate Change Canada. National Inventory Report 1990-2016: Greenhouse Gas Sources and Sinks in Canada. Available online: https:/ / publications.gc.ca/collections/collection_2018/eccc/En81-4-2016-1-eng.pdf (accessed on 11 July 2021).

15. Oil Sands Magazine. Available online: http://www.oilsandsmagazine.com/technical/bitumen-upgrading (accessed on 21 May 2020).

16. Oil Sands Magazine. Available online: http://www.oilsandsmagazine.com/technical/mining (accessed on 19 August 2020).

17. Nimana, B.; Canter, C.; Kumar, A. Energy consumption and greenhouse gas emissions in the recovery and extraction of crude bitumen from Canada's oil sands. Appl. Energy 2015, 143, 189-199. [CrossRef]

18. Charpentier, A.D.; Kofoworola, O.; Bergerson, J.A.; MacLean, H.L. Life cycle greenhouse gas emissions of current oil sands technologies: GHOST model development and illustrative application. Environ. Sci. Technol. 2011, 45, 9393-9404. [CrossRef] [PubMed]

19. Bergerson, J.A.; Kofoworola, O.; Charpentier, A.D.; Sleep, S.; MacLean, H.L. Life cycle greenhouse gas emissions of current oil sands technologies: Surface mining and in situ applications. Environ. Sci. Technol. 2012, 46, 7865-7874. [CrossRef] [PubMed]

20. Cenovus Energy. Available online: http:// cenovus.com/technology/cogeneration.html (accessed on 6 September 2020).

21. Oil Sands Magazine. Available online: http://www.oilsandsmagazine.com/news/2016/7/18/mining-versus-in-situ-howenergy-companies-are-shifting-their-priorities (accessed on 6 November 2020).

22. Oil Sands Magazine. Available online: http://www.oilsandsmagazine.com/technical/in-situ (accessed on 29 October 2020).

23. Oil Sands Magazine. Available online: https://www.oilsandsmagazine.com/projects/thermal-in-situ (accessed on 4 August 2021).

24. Nyboer, J.; Groves, S. A Review of Existing Cogeneration Facilities in Canada. CIEEDAC Report: Burnaby, Canada. 2012. Available online: http:/ / docplayer.net/22262019-A-review-of-existing-cogeneration-facilities-in-canada.html (accessed on 19 December 2020).

25. Desiderata Energy Consulting Inc. 2014 Oil Sands Co-Generation and Connection Report. Oil Sands Community Alliance Power and Co-generation Task Group Report: Calgary, Canada. 2014. Available online: https://www.oscaalberta.ca/wp-content/ uploads /2015/08/2014-Oil-Sands-Cogeneration-Report-FINAL-18-Jun-2014.pdf (accessed on 11 July 2021).

26. National Energy Board. Available online: http://www.cer-rec.gc.ca/nrg/ntgrtd/mrkt/nrgsstmprfls/ab-eng.html (accessed on 18 January 2020).

27. Bredeson, L.; Quiceno-Gonzalez, R.; Riera-Palou, X.; Harrison, A. Factors driving refinery $\mathrm{CO}_{2}$ intensity, with allocation into products. Int. J. Life Cycle Assess. 2010, 15, 817-826. [CrossRef]

28. Vriens, L. The End of Coal: Alberta's coal phase-out. International Institute for Sustainable Development Report: Winnipeg, Canada. 2018. Available online: https://www.iisd.org/system/files/publications/alberta-coal-phase-out.pdf (accessed on 11 July 2021).

29. Nimana, B.; Canter, C.; Kumar, A. Energy consumption and greenhouse gas emissions in upgrading and refining of Canada's oil sands products. Energy 2015, 83, 65-79. [CrossRef]

30. Brandt, A.R. Variability and uncertainty in life cycle assessment models for greenhouse gas emissions from Canadian oil sands production. Environ. Sci. Technol. 2012, 46, 1253-1261. [CrossRef] [PubMed] 
31. Netzer, D. Alberta Bitumen Processing Integration Study: Final Report. Province of Alberta Economic Development Department and the Alberta Energy Research Institute. 2006. Available online: https://open.alberta.ca/dataset/845b43b9-01d8-4431bbbe-abe0ac05c7f6/resource/a3b7bb6f-0e85-43fe-933d-d8e363ab846f/download/3529601-2006-alberta-bitumen-processingintegration-study-final-report-march-2006.pdf (accessed on 11 July 2021).

32. Jacobs Consultancy. Life Cycle Assessment Comparison of North American and Imported Crudes. Available online: http: // seeds4green.net/sites/default/files/life\%20cycle\%20analysis\%20jacobs\%20final\%20report.pdf (accessed on 23 January 2021).

33. Abella, J.P.; Bergerson, J.A. Model to investigate energy and greenhouse gas emissions implications of refining petroleum: Impacts of crude quality and refinery configuration. Environ. Sci. Technol. 2012, 46, 13037-13047. [CrossRef] [PubMed]

34. Cai, H.; Brandt, A.R.; Yeh, S.; Englander, J.G.; Han, J.; Elgowainy, A.; Wang, M.Q. Well-to-wheels greenhouse gas emissions of Canadian oil sands products: Implications for US petroleum fuels. Environ. Sci. Technol. 2015, 49, 8219-8227. [CrossRef] [PubMed]

35. Coordinating Research Council. Transportation Fuel Life Cycle Assessment: Validation and Uncertainty of Well-to-Wheel GHG Estimates: Alpharetta, USA. 2013. Available online: http:/ / crcsite.wpengine.com/wp-content/uploads/2019/05/CRC-E-102Final-Report.pdf (accessed on 30 September 2021).

36. Doluweera, G.H.; Jordaan, S.M.; Moore, M.C.; Keith, D.W.; Bergerson, J.A. Evaluating the role of cogeneration for carbon management in Alberta. Energy Policy 2011, 39, 7963-7974. [CrossRef]

37. Environment and Climate Change Canada. Canada's Greenhouse Gas and Air Pollutant Emissions Projections: 2018. Available online: https:/ / publications.gc.ca/collections/collection_2018/eccc/En1-78-2018-eng.pdf (accessed on 11 July 2021).

38. Yeh, S.; Jordaan, S.M.; Brandt, A.R.; Turetsky, M.R.; Spatari, S.; Keith, D.W. Land use greenhouse gas emissions from conventional oil production and oil sands. Environ. Sci. Technol. 2010, 44, 8766-8772. [CrossRef] [PubMed]

39. Söderbergh, B.; Robelius, F.; Aleklett, K. A crash programme scenario for the Canadian oil sands industry. Energy Policy 2007, 35, 1931-1947. [CrossRef]

40. National Energy Board. Available online: http:/ / www.neb-one.gc.ca (accessed on 17 May 2019).

41. World Bank. Available online: https:// data.worldbank.org/indicator/NY.GDP.DEFL.KD.ZG (accessed on 22 May 2021).

42. Méjean, A.; Hope, C. Supplying synthetic crude oil from Canadian oil sands: A comparative study of the costs and CO2 emissions of mining and in-situ recovery. Energy Policy 2013, 60, 27-40. [CrossRef]

43. Arezki, M.R.; Jakab, Z.; Laxton, M.D.; Matsumoto, M.A.; Nurbekyan, A.; Wang, H.; Yao, J. Oil prices and the global economy. International Monetary Fund 2017. Available online: https://www.imf.org/en/Publications/WP/Issues/2017/01/27/OilPrices-and-the-Global-Economy-44594 (accessed on 11 July 2021).

44. Millington, D.; Murillo, A.; McWhinney, R. Canadian Oil Sands Supply Costs and Development Projects (2014-2048). Canadian Energy Research Institute. Available online: https:/ / ceri.ca/studies/canadian-oil-sands-supply-costs-and-developmentprojects-2014--2048 (accessed on 13 May 2020).

45. Johnson, L.; Kralovic, P.; Romaniuk, A. Canadian Oil Sands Supply Costs and Development Projects (2016-2036). Canadian Energy Research Institute. Available online: https:/ / ceri.ca/assets/files/Study_159_Full_Report.pdf (accessed on 17 May 2020).

46. Sapkota, K.; Oni, A.O.; Kumar, A.; Linwei, M. The development of a techno-economic model for the extraction, transportation, upgrading, and shipping of Canadian oil sands products to the Asia-Pacific region. Appl. Energy 2018, 223, 273-292. [CrossRef]

47. International Energy Agency. Available online: https://www.iea.org/reports/unit-converter-and-glossary (accessed on 18 April 2021).

48. Brandt, A.R. Upstream Greenhouse Gas (GHG) Emissions from Canadian Oil Sands as a Feedstock for European Refineries. Department of Energy Resources Engineering, Stanford University: Stanford, CA, USA. 2011. Available online: https:// climateactionnetwork.ca/wp-content/uploads/2011/05/Brandt_EU_oilsands_Final.pdf (accessed on 11 July 2021).

49. Bergerson, J.A.; Keith, D.W. The truth about dirty oil: Is CCS the answer? Environ. Sci. Technol. 2010, 44, 6010-6015. [CrossRef] [PubMed]

50. Liggio, J.; Li, S.-M.; Staebler, R.M.; Hayden, K.; Darlington, A.; Mittermeier, R.L.; O’Brien, J.; McLaren, R.; Wolde, M.; Worthy, D.; et al. Measured Canadian oil sands $\mathrm{CO}_{2}$ emissions are higher than estimates made using internationally recommended methods. Nat. Commun. 2019, 10, 1-9. [CrossRef] [PubMed] 